\title{
Nepenthes as Tourism Flagship Species: the Conservation Strategies in Dayak Seberuang Settlements Area
}

\author{
Hendra Setiawan ${ }^{*}$ \\ Departement of Biology Education, Faculty of Teaching Training and Education, University of Kapuas, Sintang, Indonesia
}

\begin{abstract}
The aims of this research are to formulate the conservation strategies of lowland Nepenthes based on conservation status analysis, distribution map, and conceptualizing Nepenthes as flagship species for tourism. Research was held on January to October 2015 in Dayak Seberuang settlement areas, West Kalimantan Province, Indonesia. Literature analysis was used to identify recent conservation status of Nepenthes. Spatial analysis with open access software QGIS ver. 2.4 was used to understand the distribution of Nepenthes. Descriptive analysis and SWOT analysis was used to analyze people perception about Nepenthes. The results showed that from five lowland Nepenthes species which commonly found in West Kalimantan Province, one of them, namely Nepenthes bicalcarata is categorized as vulnerable (VU), and rest of it was categorized as least concern (LC) based on International Union for Conservation of Natural Resources (IUCN). The status of each lowland Nepenthes in West Kalimantan Province is urgent to improve because of much pressure to its population and habitat. Based on the distribution mapping, each Nepenthes has different preference of habitat. Nepenthes bicalcarata can be found only on canopy cover at peat swam forest, on the other hand, N. gracilis and N. mirabilis can be found in open area like Kerangas or secondary forest. Results of SWOT analysis showed that IFAS and EFAS score in range 4.107-4.086 which means that the conservation strategies of lowland Nepenthes in Dayak Seberuang settlements area are in growth phase to improve the Nepenthes population. There are opportunities for the use of Nepenthes as tourism flagship in West Kalimantan.
\end{abstract}

Keywords: community, conservation strategies, Nepenthes.

\section{INTRODUCTION}

Indonesia is one of country with high biodiversity resources in the world. Indonesian Institute of Sciences (LIPI-Lembaga IImu Pengetahuan Indonesia) reported that Indonesia has 1,500 species of algae, 80,000 species of fungi, 595 species of lichens, 2,197 species of fern, and $30,000-40,000$ species of spermatophyte. Indonesian flora is $15.5 \%$ from all flora of the world [1]. One of Indonesian endemic flora is Nepenthes and Indonesia is biodiversity center of Nepenthes in the world [2].

Nepenthes is a carnivorous plant which used its leaf modification known as pitcher to catch the prey. The pitcher is an adaptation to environmental stress especially the habitat with lack of nitrogen [2]. In Indonesia, Nepenthes plants are well known as useful plants and recently popular as ornamental plants because of uniqueness of its pitcher [3].

Nepenthes popular as ornamental plants, thus invite the plant hunters to gather it in nature massively. It is one of threats to

\footnotetext{
${ }^{*}$ Correspondence address:

Hendra Setiawan

Email : hendra_setiawan09@yahoo.com

Address : Faculty of Teaching Training and Education, University of Kapuas, Sintang, 78611
}

Nepenthes population in Borneo Island (Kalimantan, Sarawak, Sabah, Brunei Darussalam), besides habitat loss because of forest conversion to oil plantation [4].

The threats to Nepenthes population in nature are increasing every year [5]. It became more complex and involves so many aspects, such as economics, cultures, social, politics, environmental health, ecology, etc. To respond that threats, the conservationist need to arrange a comprehensive strategy in Nepenthes conservation from some perspective to prevent the decrease of Nepenthes population. This research was aim to formulate conservation strategies of lowland Nepenthes based on conservation status analysis, distribution map, and people perception about Nepenthes.

\section{RESEARCH METHOD \\ Study site}

This study was held in Dayak Seberuang Community settlements area which is one of traditional community in West Kalimantan Province, Indonesia [6]. This community administratively located in Sepauk Sub-district, Sintang Regency, West Kalimantan Province [3]. It is a low land area with average altitude from 0 $100 \mathrm{~m}$ asl. The common vegetation in this area is 
tropical lowland plants such as Shorea albida, Pandanus tectorius, Alstonia schoolaris, Sindora sp., Gluta renghas, Soneratia alba, and Planchonia grandis.

\section{Data collection}

The secondary data is conservation status from five lowland Nepenthes which is commonly found in 0-500 $\mathrm{m}$ asl in West Kalimantan namely N. ampullaria, N. bicalcarata, N. gracilis, $N$. mirabilis, and $N$. rafflesiana $[3,7]$. It was analyzed according to IUCN red list data (www.iucnredlist.org) which accessed on June 30, 2016. Spatial data from Nepenthes distribution was recorded with global positioning system (GPS) in each location of Nepenthes. People perception about Nepenthes was gathered through discussion and interview with chieftain, prominent figure of Dayak Seberuang People, traditional healers, and stakeholders from villages and Sub-district of Sepauk was involved as informants $[8,9]$.

\section{Data analysis}

Every status of lowland Nepenthes which commonly found in West Kalimantan Province was analyzed based on the threats aspect [10]. It then completed with data from other literature, field observation, and traditional people assessments.

Spatial data was analyzed with an open access software QGIS ver. 2.4 to construct a distribution map of Nepenthes [11,12]. Descriptive analysis was used to arrange people perception about Nepenthes [13]. SWOT analysis with IFAS and EFAS matrix was used to quantified and analyzed conservation strategy of lowland Nepenthes [14,15].

\section{RESULT AND DISCUSSION}

\section{Nepenthes Lowland Conservation Status}

Based on IUCN, the conservation status of five lowland Nepenthes which commonly found in West Kalimantan Province are least concern (LC) to Vulnerable (VU) (Table 1). Nephentes ampullaria [16], N. gracilis [17], N. mirabilis [18], N. rafflesiana [19] were categorized as low risk/least concern. Based on IUCN in 2016, conservation status of $N$. ampullaria, $N$. gracilis, and $N$. rafflesiana is need updating because the last assessment is on 16 years ago when the threats is less complex then now.

On the other hand, the population of $N$. mirabilis is increasing caused by the habit of this species which commonly lives on disturbed habitat which increase in West Kalimantan
Province by conversion of forest to agriculture fields [17]. Nepenthes bicalcarata is categorized as vulnerable $[2,20,21]$. Some of this status is not appropriate anymore to reliable condition in nature. For example, the population of $N$. rafflesiana is highly dependent to primary heath forest (Kerangas forest), whereas the scope of this habitat is decrease very fast every years caused by expansion of palm oil plantation. The worst condition is happened to $N$. bicalcarata, this species is an endemic species in northerneast part of Kalimantan Island.

This area only populated on peat swam forest and primary Kerangas forest which is decrease by forest burned from expansion of palm oil plantation and new paddy fields. Both of this Nepenthes status is need to increase into next level to maintain their natural population. Status raised is one of the solutions to maintain the population and makes local government aware about population threats in their region $[22,23]$.

Dayak Seberuang settlements area cover more than three villages which connected by the river. The habitat of lowland Nepenthes in this area is actually specific and affected by the micro climate [24]. This fact makes the conservation strategies from each habitat have to be different. Nepenthes conservation strategy, especially in Dayak Seberuang settlements area are depend on habitat where the Nepenthes lives, not based only on the species itself. Nepenthes threats is classified in category number five namely biological resource use $[10,24]$ (Table 2).

Based on field observation and discussion to prominent figures of Dayak Seberuang community, threats to Nepenthes is also related to agricultural activities (Number 2) such as slash and burn technique for paddy fields (Table 2). Special condition of Nepenthes in Dayak Seberuang People is Nepenthes directly affected by tradition especially because it has many traditional use like traditional medicine, dye material, etc. [4]. This condition can make Nepenthes population increase or decrease depends on how traditional people, local government, and related stakeholders manage it [25].

\section{Conservation Strategy of Lowland Nepenthes based on Distribution Maps}

Lowland Nepenthes which found in Dayak Seberuang settlements area is live in specific habitat. Specific habitat is some preference for each Nepenthes (Fig. 1). 
Lowland Nepenthes conservation strategies in Dayak Seberuang (Setiawan et al)

Table 1. Threats Status of Lowland Nepenthes based on IUCN

\begin{tabular}{lllll}
\hline Nepenthes species & Threats status by IUCN & Latest review & Annotations & Field observation \\
\hline N. ampullaria & LR/LC Ver. 2.3 & 2000 & Needs updating & Abundant \\
N. bicalcarata & VU B1 +2c Ver 2.3 & 2000 & Needs updating & Hardly found \\
N. gracilis & LR/LC Ver. 2.3 & 2000 & Needs updating & Abundant \\
N. mirabilis & LCVer 3.1 & 2014 & Update & Increasing \\
N. rafflesiana & LR/LC Ver. 2.3 & 2000 & Needs updating & Hardly found \\
\hline
\end{tabular}

Note: $\mathrm{LR}=$ Lower risk, $\mathrm{LC}=$ least concern, $\mathrm{VU}=$ Vulnerable

Table 2. Threats Classification of Lowland Nepenthes

\begin{tabular}{|c|c|c|c|c|c|c|c|c|c|c|c|}
\hline \multirow{2}{*}{ Nepenthes Species } & \multicolumn{11}{|c|}{ First level threat category } \\
\hline & 1 & 2 & 3 & 4 & 5 & 6 & 7 & 8 & 9 & 10 & 11 \\
\hline N. ampullaria & & $x^{*}$ & & & $X *[5]$ & & & & & & \\
\hline N. biclcarata & & $\mathrm{X}^{*}$ & & & $X *[2]$ & & & & & & \\
\hline N. gracilis & & $\mathrm{X}^{*}$ & & & $X *[5]$ & & & & & & \\
\hline N. mirabilis & & $\mathrm{X}^{*}$ & & & $X *[2]$ & & & & & & \\
\hline N. rafflesiana & & $\mathrm{X}^{*}$ & & & $X *[5]$ & & & & & & \\
\hline
\end{tabular}

1. Residential \& commercial development, 2. Agriculture and aquaculture, 3. Energy production and mining, 4. Transportation and services corridors, 5. Biological resources use, 6. Human intrusions and disturbance, 7. Natural systems modifications, 8. Invasive and other problematic species and genes, 9. Pollution, 10. Geological events, and 11. Climate change and severe weather.

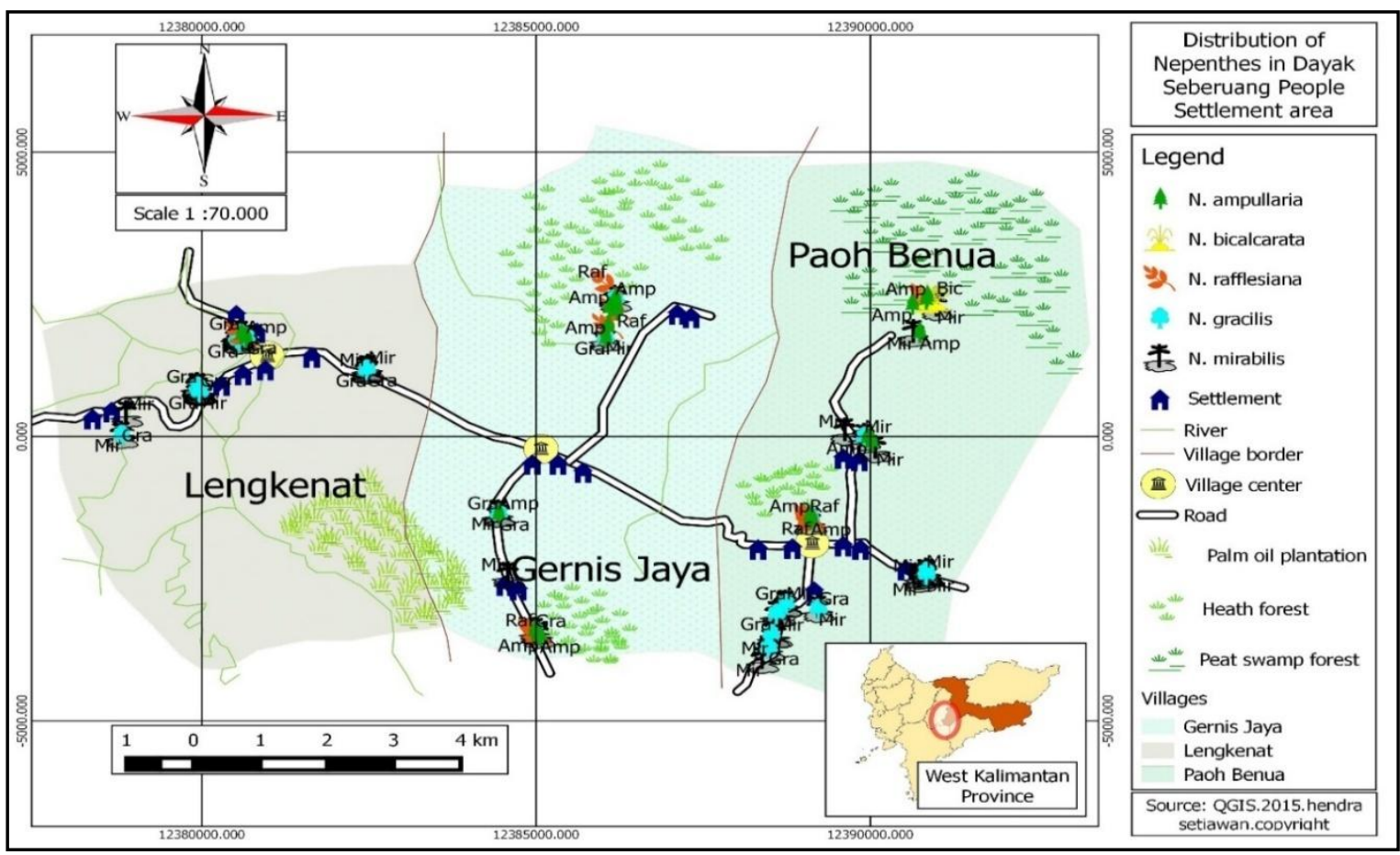

Figure 1. Map of Nepenthes Distribution in Dayak Seberuang People Settlements Area

Nepenthes ampullaria can be found in secondary forest with open canopy, heath forest (Kerangas forest), peat swam forest, and edge of lake. Nepenthes bicalcarata only can be found in peat swamp forest. Nepenthes gracilis and $N$. mirabilis commonly found in an open canopy area like secondary forest and disturbed habitat. Nepenthes rafflesiana commonly found in primary Kerangas forest and peat swamp forest. In some condition, Nepenthes can be found lives side by side with other Nepenthes. Nepenthes bicalcarata can be found with $N$. ampullaria and
$N$. rafflesiana but never found with $N$. gracilis and $N$. mirabilis. Nepenthes ampullaria can lives with all lowland Nepenthes in this area (Fig. 1). This habitat preference can make some point to arrange the conservation strategy for lowland Nepenthes especially in Dayak Seberuang settlement area. $\mathrm{P}$

Preference of Nepenthes distribution in their habitat affected by physical-chemical factors such as soil organic matter (SOM), $\mathrm{pH}$, and light intensity $[2,21,26]$. Soil organic matter is spread out vary in each habitat which caused by a long 
time process of soil weathering. It affects other soil physical-chemical factors like soil acidic level $(\mathrm{pH})$, canopy coverage, light intensity, temperature, humidity, etc. The distribution of SOM and other factors effected the distribution of Nepenthes in natural habitat [26]. Nepenthes bicalcarata and $N$. rafflesiana disposed to lives in habitat with high contain soil organic matter and low light intensity like peat swamp forest and primary heath forest (Fig. 1). Nepenthes gracilis and $N$. mirbilis commonly found in open area with low SOM and high light intensity (Fig. 1). Nepenthes ampullaria can be found in almost all Nepenthes habitat in lowland area $[2,21]$.

Nepenthes distribution's map can be use as source/references for arrangement of Nepenthes conservation strategy. Preference of Nepenthes distribution specific to some habitat is the main point in Nepenthes conservation strategy. Specific habitat is the main target to conserve Nepenthes. For example, N. bicalcarata in Dayak Seberuang settlement area only found in peat swamp forest, its mean that the peat swamp forest is a primary target to conserve and maintain the population of $\mathrm{N}$. bicalcarata (Fig.1). Distribution map is a common tools in arrange the conservation strategy and policy to be more effective and accurate on target [27].

\section{Conservation Strategy of Lowland Nepenthes}

Internal factors of SWOT analysis consist of strengths and weakness. The highest score of strengths factor is that traditional people still respect the culture in the highest level and it score is 0.893 (Table 3 ). This factor supported by traditional events which held every year to celebrate the expression of gratitude to the Creator and Owner of universe known in Dayak Seberuang believe as Betara Puyang Gana for the harvest in that years (Fig. 2). Cultures and traditional values are important factors to conserve the biodiversity [28,29]. Otherwise, cultures degradation in young generation of Dayak Seberuang People is the highest score of weakness factor with score 0.893 (Table 3). This condition is affected by weak of awareness from young generation about traditional values. It also caused by high impact of modernization with lack guidance from elders [30,31]. Over all, total score of internal factors is 4.107 which in strong level (Table 3).

External factor which has the highest impact to Nepenthes conservation is the opportunities of support from local government to conserved endemic Nepenthes with score 0.776 (Table 4).
Local government, in this case is Sintang Regency is made Nepenthes as one of their new mascot. The Nepenthes mascot can be found in entrance gate of Sintang Regency from Pontianak. The reason of Sintang Regency made Nepenthesas a mascot is that there were found at least 11 species with one species, namely $N$. clipeata is one of the most rare and endangered Nepenthes in the world $[2,7,21]$. The highest score of threats factors is the expansion of palm oil plantation around custom forest with score is 0.862 (Table 4). Palm oil expansion is happening massively in all over Kalimantan Island, especially in West Kalimantan. Kalimantan Island lost $30.7 \%$ of their forest in 1973-2010 and it will continue while palm oil expansion still allowed [4]. Kalimantan Island is the center of Nepenthes distribution in the world, loss of habitat and forest in Kalimantan is mean loss of Nepenthes population too [2]. The total score of external factors is 4.086 (Table 4) which means that external factors support Nepenthes conservation in strong level.

The combination of internal and external factors showed that lowland Nepenthes conservation strategy in Dayak Seberuang People settlements area is in growth phase with ratio 4.107 : 4.086 (Fig. 3). It means that the conservation strategy will be succeed if the collaboration from Dayak Seberuang people, local government, researchers from local collages, and NGO's can complements each other. This collaboration will have important roles in Nepenthes conservation. If conservation only done by some people/organization, the results of it will be not optimal $[14,32,33]$.

Some recommendation for conservation Strategy of lowland Nepenthes in Dayak Seberuang Settlements area as follow:

1. Nepenthes which categorized as high threats based on IUCN and Salafsky conservation threats [10] should be priorities to conserve

2. The location of vulnerable Nepenthes should be protected by local wisdom (custom forest) and also by government laws

3. Based on IFAS and EFAS of Nepenthes in Dayak Seberuang People, Nepenthes is a potential plant to conserve especially because of high respect from local people and also the support from local government to protect and conserve the Nepenthes as a new local icon. 
Table 3. IFAS matrix (Internal Factors Analysis Summary)

\begin{tabular}{|c|c|c|c|}
\hline Internal Factors & Weights & Rating & Score \\
\hline \multicolumn{4}{|l|}{ Strengths } \\
\hline Traditional people respect the culture in the highest level & 0.179 & 5 & 0.893 \\
\hline High support from chieftain and prominent figure of Dayak Seberuang People & 0.143 & 4 & 0.571 \\
\hline Existence of endemic Nepenthes & 0.107 & 5 & 0.536 \\
\hline Traditional people pretention to make Nepenthes as sustainable income & 0.071 & 3 & 0.214 \\
\hline $\begin{array}{l}\text { Traditional people from three village of Dayak Seberuang People wants to protect the remaining } \\
\text { forest with indigenous knowledge }\end{array}$ & 0.036 & 3 & 0.107 \\
\hline \multicolumn{4}{|l|}{ Weakness } \\
\hline Cultures degradation of indigenous knowledge in young generation of Dayak Seberuang People & 0.179 & 5 & 0.893 \\
\hline Limited of qualified human resources & 0.107 & 4 & 0.429 \\
\hline People' custom which open the paddy fields with slush and burn technique & 0.071 & 2 & 0.143 \\
\hline Most of traditional people have no knowledge of endemic species in their land & 0.071 & 3 & 0.214 \\
\hline Lack of supporting facilities to Nepenthes development and cultivation & 0.036 & 3 & 0.107 \\
\hline Total score & 1 & & 4.107 \\
\hline
\end{tabular}

Table 4. EFAS Matrix (External Factors Analysis Summary)

\begin{tabular}{|c|c|c|c|}
\hline External Factors & Weight & Rating & Score \\
\hline \multicolumn{4}{|l|}{ Opportunities } \\
\hline Support from local government to conserved endemic Nepenthes & 0.155 & 5 & 0.776 \\
\hline Program from Ministry of Rural Development to support GDP & 0.121 & 4 & 0.483 \\
\hline Increasing of people interest in Nepenthes cultivation & 0.086 & 4 & 0.345 \\
\hline Support from local academic/collages in conservation of endemic Nepenthes & 0.086 & 3 & 0.259 \\
\hline Support from conservation NGO's to protect local biodiversity & 0.034 & 3 & 0.103 \\
\hline \multicolumn{4}{|l|}{ Threats } \\
\hline Threats from palm oil plantation expansion around custom forest & 0.172 & 5 & 0.862 \\
\hline Forest burn caused by palm oil plantation & 0.155 & 5 & 0.776 \\
\hline Over exploitation of Nepenthes by collector & 0.103 & 3 & 0.310 \\
\hline Lack of coordination between village or region in biodiversity conservation & 0.052 & 2 & 0.103 \\
\hline Limited access to large area in over three village of Dayak Seberuang People & 0.034 & 2 & 0.069 \\
\hline Total score & 1 & & 4.086 \\
\hline
\end{tabular}

\section{Nepenthes As flagship species in tourism}

Nepenthes has potential value as tourism flagship species in Kalimantan. The value of Nepenthes in flagships is attracting tourist interest in various aspects, including conservation action to support Nepenthes through numerous tourism activities. It is includes education to increase tourist awareness in Nepenthes conservation, increase tourism involvement in planting Nepenthes in natural habitat, and numerous education program to improve tourist understanding about ecology and biology of Nepenthes. It is especially important and relevant with the objective of ecotourism to support conservation.

The idea of the use of flora and fauna as flagship species has been suggested by scholars $[34,35]$. The charismatic species often attract tourist to visit some particular area, such as komodo in Komodo National park or Orang utan in Tanjung Puting National Park. There is also possibility to use Nepenthes to attract tourist. In such a case, the conservation of Nepenthes is crucial.

Local community, local government and tourism planer have expressed their concern about Nepenthes as tourism flagship species in Dayak Seberuang in West Kalimantan. Nepenthes are considered high priority in tourism image development as flagship species. It is based on Nepenthes importance in the daily live of local people in Dayak Seberuang.

\section{CONCLUSION}

Nepenthes conservation strategy has to be formulated from different perspective to overcoming the Nepenthes threat which become more complex every time. Nepenthes conservation status analysis can be use to determine the priority of conservation action, Nepenthes which have critical status should be priority for conservation. Nepenthes distribution data analysis used open access software QGIS 2.4 produced the range area of Nepenthes 
distribution center and other ecological factor which affect Nepenthes population.

People perception analysis about Nepenthes and it threats can be use to formulate Nepenthes conservation strategy based on indigenous knowledge perspective. People perception with IFAS and EFAS score in range $4.107: 4.086$ means that the conservation strategies of lowland Nepenthes in Dayak Seberuang settlements area are in growth phase to improve the Nepenthes population. Conservation strategies of common lowland Nepenthes in West Kalimantan should be based on people perception and indigenous knowledge which combined with natural condition like Nepenthes distribution and it preference. Nepenthes has significant value as tourism destination icon, especially for tourism flagship species.

\section{ACKNOWLEDGEMENT}

The author would like to thank Dr. Luchman Hakim and Dr. Jati Batoro for the help in advancing the discussion to write this paper.

\section{REFERENCES}

[1] Abdulhadi, R (Ed). 2014. Kekinian keanekaragaman hayati Indonesia. Indonesian Institute of Science, Ministry of National Development - Ministry of Environment. Jakarta.

[2] Clarke, C. M. 2006. Nepenthes of Borneo. Natural History Publications (Borneo) Sdn, Bhd. Sabah.

[3] Setiawan, H., L. Hakim and J. Batoro. 2015. Ethnobotany of Nepenthes spp. in Dayak Seberuang People, West Kalimantan, Indonesia. Journal of Biodiversity and Environmental Science 7(6), 275-284.

[4] Gaveau, D. L. A., S. Sloan, E. Molidena, H. Yaen, D. Sheil, N. K. Abram, M. Ancrenaz, R. Nasi, M. Quinones, N. Wielaard and E. Meijaard. 2014. Four decades of forest persistence, clearance and logging on Borneo. PLoS ONE 9 (7), e101654.

[5] Jennings, D. E. and J. R. Rohr. 2011. A review of the conservation threats to carnivorous plants. Biological Conservation 144, 1356-1363.

[6] Alloy, S., A. Albertus and C. P. Istiyani. 2008. Mozaik Dayak: keberagaman Sub suku dan bahasa Dayak di Kalimantan Barat. Institut Dayakologi. Pontianak.

[7] Listiawati, A. and C. Siregar. 2008. Entuyut (Nepenthes) asal Kalimantan Barat. Tanjungpura University Press. Pontianak.
[8] Srianta, I., J. H. Arisasmita, H. D. Patria and I. Epriliati. 2012. Ethnobotany, nutritional composition and DPPH radical scavenging of leafy vegetables of wild Paederia foetida and Erechtites hieracifolia. International Food Research Journal 19(1), 245-250.

[9] Kalala, W. M., J. J. Magadula, R. H. Mdegela. 2014. Ethnobotanical use of Commiphora swynertonii Burrt. amongst Dorobo People in Tanzania. Journal of Medicinal Plant Research 8(23), 820-828.

[10] Salafsky, N., D. Salzer, A. J. Stattersfield, C. Hilton-Taylor, R. Neugarten, S. H. M. Butchart, B. Collen, N. Cox, L. L. Master, S. O'Connor and D. Wilkie. 2008. A standard Lexicon for biodiversity conservation: unified classifications of threats and actions. Conservation Biology Volume 22(4), 897911.

[11] Bunch, M. J., T. V. Kumaran and R. Joseph. 2012. Using Geographic Information Systems (GIS) for spatial planning and environmental management in India: critical considerations. International Journal of Applied Science and Technology 2(2), 40-54.

[12] Putri, W. K., A. Naim and H. Setiawan. 2015. Fruit plants species along corridor in Kopendukuh Village as a resource for rural tourism development. Journal of Indonesian Tourism and Development Studies 3(1), 3136.

[13] Zulia, Z. and B. Yanuwiadi. 2015. The natural and cultural resources for ecotourism development in Trenggalek Regency, East Java. Journal of Indonesian Tourism and Development Studies 3(2), 45-52.

[14] Sayyed, M. R. G., M. S. Mansoori and R. G. Jaybhaye. 2013. SWOT analysis of Tandooreh National Park (NE Iran) for sustainable ecotourism. Proceedings. International Academy of Ecology and Environmental Sciences 3(4), 296-305.

[15] Butarbutar, R. R., M. Purnomo, L. Hakim, I. Rochdjatun and S. Soemarno. 2014. Strategic development of nature tourism based on plant species at the Mahawu mountainous region, North Sulawesi, Indonesia. Journal of Biodiversity and Environmental Sciences (5)5, 241-252.

[16] Clarke, C., R. Cantley, J. Nerz, H. Rischer and A. Witsuba. 2000. Nepenthes ampullaria. The IUCN Red List of Threatened Species 2000: e.T39640A10253611. Available at: http://dx.doi.org/10.2305/IUCN.UK.2000.RL TS.T39640A10253611.en. 
[17] Clarke, C., R. Cantley, J. Nerz, H. Rischer and A. Witsuba. 2000. Nepenthes gracilis. The IUCN Red List of Threatened Species 2000: e.T39663A10254967. Available at: http://dx.doi.org/10.2305/IUCN.UK.2000.RL TS.T39663A10254967.en.

[18] Clarke, C. M. 2014. Nepenthes mirabilis. The IUCN Red List of Threatened Species 2014: e.T49122515A21844202. Available at: http://dx.doi.org/10.2305/IUCN.UK.20141.RLTS.T49122515A21844202.en.

[19] Clarke, C., R. Cantley, J. Nerz, H. Rischer and A. Witsuba. 2000. Nepenthes rafflesiana. The IUCN Red List of Threatened Species 2000: e.T39689A10251466. Available at: http://dx.doi.org/10.2305/IUCN.UK.2000.RL TS.T39689A10251466.en.

[20] Schnell, D., P. Catling, G. Folkerts, C. Frost, R. Gardner, et al. 2000. Nepenthes bicalcarata. The IUCN Red List of Threatened Species e.T39624A10252393. Available at: http://dx.doi.org/10.2305/IUCN.UK.2000.RL TS.T39624A10252393.en.

[21] Mansur, M. 2006. Nepenthes, Kantong Semar yang unik. Penebar Swadaya. Depok.

[22] Andel, T. R. V., S. Croft, E. E. V. Loon, D. Quiroz, A. M. Towns and N. Raes. 2015. Prioritizing West African medicinal plants for conservation and sustainable extraction studies based on market surveys and species distribution models. Biological Conservation 181, 173-181.

[23] Andreou, M., C. Kadis, P. Delipetrou and K. Georghiou. 2015. Conservation biology of Chionodoxa lochiae and Scilla morrisii (Asparagaceae): Two priority bulbous plant species of the European Union in Cyprus. Global Ecology and Conservation 3, 511525.

[24] Batori, Z., A. Lengyel, M. Maroti, L. Kormoczi, C. Tolgyesi, A. Biro, M. Toth, Z. Kincses, V. Cseh and L. Erdos. 2014. Microclimate-vegetation relationships in natural habitat islands: species preservation and conservation perspectives. Quarterly Journal of the Hungarian Meteorological Service 118(3), 257-281.

[25] Schwallier, R., H. J. D. Boer, N. Visser, R. R. van Vugt and B. Gravendeel. 2015. Traps as treats: a traditional sticky rice snack persisting in rapidly changing Asian kitchens. Journal of Ethnobiology and Ethnomedicine 11, 24-32.
[26] Fleming, R. L., R. F., Powers, N. W., Foster, J. M. Kranabetter, D. A. Scott, F. J. Ponder, S. Berch, W. K. Chapman, R. D. Kabzems, K. H. Ludovici, D. M. Morris, D. S. PageDumroese, P. T. Sanborn, F. G. Sanchez, D. M. Stone and A. E. Tiarks. 2006. Effects of organic matter removal, soil compaction, and vegetation control on 5-year seedling performance: a regional comparison of Long-Term Soil Productivity sites. Canadian Journal of Forest Research 36, 529-550.

[27] Bajjouk, T., S. Rochette, M. Laurans, A. Erhold, A. Hamdi and P. L. Niliot. 2015. Multi-approach mapping to help spatial planning and management of the kelp species L. digitata and L. hyperborea: Case study of the Molène Archipelago, Brittany. Journal of Sea Research 100, 2-21.

[28] Silva, T. C. D., M. A. Ramos, Schwarz, I. A. Alvarez, L. H. P. Kill and U. P. D. Albuquerque. 2014. Local representations of change and conservation of the riparian forests along the São Francisco River (Northeast Brazil). Forest Policy and Economics 45, 1-12.

[29] Gadamus, L., J. Raymond-Yakoubian, R. Ashenfelter, A. Ahmasuk, V. Metcalf and G. Noongwook. 2015. Building an indigenous evidence-base for tribally-led habitat conservation policies. Marine Policy 62, 116-124.

[30] Chand, V. S. and S. R. Shukla. 2003. Biodiversity contests: indigenously informed and transformed environmental education. Applied Environmental Education and Communication (2)4, 229-236.

[31] Risirio, J., D. T. Tshuma and A. Basikiti. 2013. Indigenous knowledge systems and environmental management: a case study of Zaka District, Masvingo Province, Zimbabwe. International Journal of Academic Research in Progressive Education and Development 2(1), 19-39.

[32] Martin-Collado, D., C. Diaz, A. Maki-Tanila, F. Colinet, D. Duclos, J. Hiesmtra and G. Gandini, 2013. The use of SWOT analysis to explore and prioritize conservation and development strategies for local cattle breeds. Animal 7(6), 885-894.

[33] Nisa, A.R.K., S. Samino, E. Arisoesilaningsih. 2014. Agroedutourism and ecopreneurship activities on the organic farming practices in Lawang, Malang Regency, East Java, Indonesia. Journal of Indonesian Tourism and Development Studies 2(3), 103-113. 
[34] Walpole, M. J. and N. Leader-Williams, 2002. Tourism and flagship species in conservation. Biodiversity and Conservation 11(3), 543-547.

[35] Veríssimo, D., I. Fraser, J. Groombridge, R. Bristol and D. C. MacMillan. 2009. Birds as tourism flagship species: a case study of tropical islands. Animal Conservation 12(6), 549-558. 